\title{
The Costs and Benefits of Regulating the Market for Corporate Insolvency Practitioner Remuneration
}

The release by the Australian Treasury on Friday, 7 November, 2014 of the Insolvency Law Reform Bill (ILRB) 2014 throws the spotlight once again on corporate insolvency law reform in Australia. Significantly, the ILRB 2014 identifies amongst its purposes two objectives with respect to Corporate Insolvency Practitioner (CIP) remuneration reform. Namely to: promote market competition on price and quality and improve the overall confidence in the professionalism and competence of insolvency practitioners. This paper considers whether the proposed CIP remuneration reforms outlined in the ILRB 2014 will effectively achieve these objectives. Where it is considered reforms are misdirected, further changes, informed by United Kingdom insolvency reform proposals, are considered.

Dr Jennifer Dickfos, Griffith University, Australia

Email: j.dickfos@griffith.edu.au

Phone: +61 (0)7 55528812 (work) +61(0) 40228760 (mobile)

Fax: +61 (0)7 55528068 


\section{INTRODUCTION}

The release by the Australian Treasury on Friday, 7 November, 2014 of the Insolvency Law Reform Bill (ILRB) 2014 throws the spotlight once again on personal and corporate insolvency law reform in Australia, which at best has been a protracted process. The regulation of the Australian insolvency industry and its practitioners in particular has been the subject of no less than eight major reviews and enquiries over the last twenty-five years. ${ }^{1}$ The change of government in Australia in 2013 saw the temporary stalling of insolvency law reform with the mothballing of the Insolvency Law Reform Bill 2013. However, the 2014 ILRB mirrors to a large extent the 2013 version.

Significantly, with respect to CIP remuneration reform, the ILRB 2014 identifies amongst its purposes two objectives which earlier reviews, such as the Harmer Report, the PJC Report and the Senate Committee Report also sought to achieve:

(i) Promote market competition on price and quality;

(ii) Improve the overall confidence in the professionalism and competence of insolvency practitioners. $^{2}$

The important role remuneration plays in the development, performance and public perception of the IP profession cannot be overstated. Remuneration is one of seven benchmarks identified by the European Bank for Reconstruction and Development (EBRD) in their review

\footnotetext{
${ }^{1}$ For a comparison of the various recommendations made by The Australian Law Reform Commission (ALRC), General Insolvency Inquiry Report No 45 (1988) known as the Harmer Report; Commonwealth of Australia, Review of the Regulation of Corporate Insolvency Practitioners known as the Working Party Report 1997; Parliamentary Joint Committee on Corporations and Financial Services, Corporate Insolvency Laws: A Stocktake, known as the PJC Report and Parliament of Australia, Senate Economics References Committee, The Regulation, Registration and Remuneration of Insolvency Practitioners in Australia: The Case for a New Framework (2010) known as The Senate Report see Jennifer Dickfos, “The Regulation of Corporate Insolvency Practitioners: 25 Years on from The Harmer Report (or Everything Old is New Again)” (2014) 2 NIBLeJ 3.

${ }^{2}$ Commonwealth of Australia, Exposure Draft Insolvency Law Reform Bill 2014 [1.1].
} 
of IPs across 27 of the 35 countries where the bank invests. ${ }^{3}$ The EBRD considers not only that a statutory framework for IP remuneration should exist to regulate the payment of IP fees, provide incentives for IPs to perform well and to protect stakeholders (including the payment of IP fees in liquidation), but a more rigorous assessment of how effective IPs are in their work and related practices should extend to the issue: Do IPs provide 'value for money'?

Public confidence and trust in the corporate insolvency regime, including its practitioners, requires Corporate Insolvency Practitioners (CIPs) receive a fair and reasonable amount of remuneration to perform their role proficiently so as to allow financially troubled companies to remain in business, or where this is impossible, to maximise the returns of vulnerable creditors. However, media reports ${ }^{4}$ emphasising the excessive level and poor disclosure of CIP remuneration continue to dog the insolvency profession reducing the public's confidence and trust in CIPs.

The conundrum is creditor approval of CIP remuneration is inherently conflicted. CIPs are entitled to be adequately rewarded for their services. However, creditors’ returns are directly impacted by the level of CIP remuneration paid, where CIP remuneration is paid out of the finite assets of an insolvent company. However, if CIP remuneration rates are poor, then the insolvency profession may not attract good quality entrants, leading to poorly skilled,

\footnotetext{
${ }^{3}$ For details of the seven benchmarks see European Bank for Reconstruction and Development, Assessment of Performance of Insolvency Office Holders Discussion Paper (EBRD, 2012) (EBRD Discussion Paper) Available at www.ebrd.com/downloads/legal/insolvency/discuss.pdf For the Final Report see European Bank for Reconstruction \& Development, Assessment of Insolvency Office Holders: Review of the profession in the EBRD Region, (EBRD, 2014) available at http://assessment.ebrd.com/insolvency-officeholders/2014/report.html Both reports are informed by the EBRD Principles in Respect of the Qualification, Appointment, Conduct, Supervision and Regulation of Office Holders in Insolvency Cases,(European Bank for Reconstruction and Development, June 2007), 10. Available at http://www.ebrd.com/downloads/legal/insolvency/ioh principles.pdf

${ }^{4}$ National Party Senator for New South Wales, John William's publicly expressed concerns, at the conduct (including excessive remuneration charges) of some insolvency practitioners. In particular, Stuart Ariff was the catalyst for the 2010 Senate Economics References Committee Inquiry into the conduct of the insolvency profession in Australia and the adequacy of efforts to monitor, regulate and discipline misconduct. ASIC brought criminal proceedings against Stuart Ariff which resulted in the former liquidator being found guilty on 19 criminal charges and jailed for six years in 2011. For more recent examples of media scrutiny see, “Liquidators Taken to Task over \$500,000 in Legal fees” Australian Financial Review, 29 October, 2014; “Fee Challenge Rattles Experts”The West Australian, $22^{\text {nd }}$ November, 2014; “Courtroom battler has his day with insolvency judgement” The Age, 11 December, 2014.
} 
inefficient or at worst corrupt insolvency professionals, and little if any public confidence in IPs and the insolvency profession generally. Consequently a balance must be struck when creditors approve CIP remuneration.

Current regulation of CIP remuneration in Australia is a mixture of self-regulatory and statutory market disclosure measures reflecting the reliance upon the market, to determine the most cost - effective remuneration - setting mechanism for CIPs. Theoretically, a competitive market for CIP services should provide creditors with adequate protection from unscrupulous CIPs. ${ }^{5}$ However if there is market failure, for example, inadequate competition, or information asymmetries, Ogus $^{6}$ argues that regulation is necessary to provide such protection.

This paper considers first: whether there is market failure within Australia’s CIP market or are such claims ill-founded. Secondly, if inadequate competition or information asymmetries do exist within Australia's CIP market whether the proposed CIP remuneration reforms outlined in the ILRB 2014 effectively address these market failures. To answer this question the remainder of this article is organised as follows: Section 2 outlines the current Australian measures in place to control CIP remuneration; followed by Section 3 which summarises the main criticisms with the present regulatory framework for CIP Remuneration. Section 4 then considers whether the ILRB 2014's proposed changes sufficiently address these criticisms or if further changes, informed by proposed United Kingdom insolvency reforms are warranted. Conclusions are then drawn in Section 5.

\section{CURRENT REGULATION OF CIP REMUNERATION IN AUSTRALIA}

\footnotetext{
${ }^{5}$ Robyn Hollander, 'Rethinking Regulation after the Crash' in Elizabeth van Acker and Giorel Curran, (eds) Government and Business in Volatile Times (2013) 217, 222.

${ }^{6}$ Anthony Ogus, Regulation: Legal Form and Economic Theory (1994), Chapter 3.
} 


\subsection{Self-Regulatory Measures}

The professional body ARITA (the Australian Restructuring Insolvency and Turnaround Association) formerly the Insolvency Practitioners Association of Australia (IPAA), represents the majority of insolvency practitioners within Australia. ${ }^{7}$ ARITA's Code of Professional Practice provides three overarching principles of remuneration: the work is 'necessary and proper'; a fee claim is accompanied by 'sufficient, meaningful, open and clear disclosure' and approval is gained and recorded before remuneration is drawn. ${ }^{8}$

The Code does not give preference to any method of fee calculation, although currently, the most popular method of fee setting is an hourly rate basis. Rather, the Code requires its members to inform creditors of the various methods of calculating remuneration: time based hourly rates charging; fixed fee; percentage of assets disclosed, or assets realised; success or contingency fees. ${ }^{9}$ Insolvency practitioners are further required to inform creditors at the commencement of the administration, of their respective choice of remuneration setting, and their justification for such choice. Where time based charging is the preferred method of remuneration setting, the scale of rates that will be used, including qualifications and experience of staff at each level; and an estimate of administration costs to completion or to a specific milestone is to be provided.

During the administration, before any creditors' meeting is held at which approval for remuneration is sought, members, using time based charging, should complete ARITA's Recommended Remuneration Report template ${ }^{10}$ as the means of giving creditors the information they need to make an informed decision as to the reasonableness of the remuneration sought.

\footnotetext{
${ }^{7}$ As of December, 2013, 80\% of all registered liquidators and 91\% of all Bankruptcy Trustees in Australia are ARITA members. Available at www.arita.com.au/insolvency-you/look-up-a-member

${ }^{8}$ Principles 10, 11 and 12 ARITA Code of Professional Conduct. Available at http://www.arita.com.au

${ }^{9}$ Sections15.2.1- 15.2.5 ARITA Code of Professional Conduct. Available at http://www.arita.com.au/

${ }^{10}$ Section 23.2.2 ARITA Code of Professional Conduct. Available at http://www.arita.com.au/ The Code suggests that aspects of the report may be suitable where other remuneration bases are used.
} 
Disbursements ${ }^{11}$ do not form part of an IP's remuneration and therefore are not subject to creditor approval, although CIPs must still be accountable to creditors for such

disbursements. The Code requires disclosure of disbursements in three categories: externally provided professional services; externally provided non-professional costs; and internal disbursements which are recoverable at cost. Disbursements may only be claimed if they are necessary and properly incurred.

\subsection{Statutory Regulation}

In assessing the remuneration of CIPs the EBRD identified two remuneration setting options:

“a tariff (eg. a percentage of realisations and/or distributions ) that represents a fair return for the work involved or to allow remuneration to be set by market forces.”12

Whilst the Corporations Act (Cth) provide CIPs with a right to remuneration ${ }^{13}$ and contemplates various methods of calculating such, the law does not prescribe a particular method for calculating remuneration in any external administration. Instead, reliance is placed upon the CIP's mandatory disclosure of a summarised description, including costs of the major tasks performed or to be performed in a remuneration report, ${ }^{14}$ to enable the

\footnotetext{
${ }^{11}$ Section 14.10.1 ARITA Code of Professional Conduct Available at http://www.arita.com.au/ The Code defines disbursements as: costs paid from the Administration's bank account directly to third parties; or costs paid to third parties by the Practitioner and later claimed back from the Administration; or costs claimed by the Practitioner for non-professional services provided by the Firm and/or outlays incurred by their staff in the proper conduct of the Administration.

${ }^{12}$ European Bank for Reconstruction and Development, Assessment of Performance of Insolvency Office Holders Discussion Paper (EBRD, 2012, 18) Available at www.ebrd.com/downloads/legal/insolvency/discuss.pdf

${ }^{13}$ Section 473(3) Corporations Act 2001 (Cth) for court liquidations; s495 (1), s499 (3) and s504 (1) for voluntary liquidations and s473 (2) for provisional liquidations. Although s473(4A), s499(3) Corporations Act 2001 (Cth) allows for minimum fixed remuneration in circumstances where if the total remuneration payable to a trustee is less than $\$ 5000$, or where on liquidation the practitioner has convened a creditors meeting but the resolution did not pass due to a lack of quorum.

${ }^{14}$ The Corporations Amendment (Insolvency) Bill 2007 amended the Corporations Act 2001 to require CIPS to prepare a report of their fees for creditors. See subsections: ss449E (5)-(7) voluntary administration; ss473 (11) and (12) court appointed liquidations; ss499 (6) and s499(7) creditor's voluntary liquidation. In the following year (2008) the IPA (now ARITA) amended its Code of Professional Practice to include the three principles of remuneration and ASIC released Information Sheet 85, 'Approving fees: A guide for creditors'.
} 
committee of creditors or creditors to determine if the proposed remuneration is reasonable. ${ }^{15}$ If creditors cannot agree upon the remuneration sought, the administrator may apply to the court to have his remuneration determined. ${ }^{16}$ Further, scrutiny is possible as any creditor, member or liquidator may apply to the Court to review the amount of the liquidator's remuneration. The Court, whose decision is final and conclusive, ${ }^{17}$ is provided statutory guidance ${ }^{18}$ of the relevant considerations for remuneration setting. Such factors include: the extent to which the work was reasonably necessary; the period during which the work was performed and the quality and complexity of the work performed. ${ }^{19}$

\section{CONTINUING CRITICISM OF CIP REMUNERATION}

\subsection{Information Asymmetries}

Current self-regulatory and statutory disclosure requirements imposed on CIPs would appear to address information asymmetries regarding the reasonableness of CIP remuneration, especially in regard to the time and scale of fees charged by an administrator. Creditors have the opportunity to oversee the reasonableness and potentially control the likely administrator remuneration costs to be incurred, where an estimate of the fees to be charged in conjunction with a fee cap (where remuneration is based on a time-cost basis) is provided at the time of seeking initial creditor fee approval.

However, it has been observed in the context of consumer protection "that information asymmetry can arise between consumers and providers of financial products as consumers

\footnotetext{
${ }^{15}$ See ss473 (11) \& (12) Corporations Act 2001 (Cth) for court appointed liquidations; s499 (6) \& (7) Corporations Act 2001 (Cth) for voluntary liquidation, s449E(5) Corporations Act 2001 (Cth) for voluntary administration and s449E(6) Corporations Act 2001 (Cth) for deed of company arrangement.

${ }^{16}$ Section 449E (1) Corporations Act 2001 (Cth) Voluntary administrator, s449E (1A) DOCA administrator, s473 (3)(b) Court appointed liquidator, s504(1) Liquidator may apply to the Court for review of his remuneration.

${ }^{17}$ Section 504 (1) (voluntary winding up); S473 (5) \& (6) (compulsory winding up) Corporations Act 2001 (Cth).

${ }^{18}$ Section 473(10) and s504 (2) Corporations Act 2001 (Cth).

${ }^{19}$ Ibid.
} 
lack (and cannot efficiently obtain) the knowledge, experience or judgment required to make informed decisions... a situation where further disclosure, no matter how high quality or comprehensive, cannot overcome market failure”. ${ }^{20}$ Certainly the question of whether the current CIP's remuneration report contains too much information for the average unsecured creditor to comprehend was raised in the 2010 Senate Inquiry. ${ }^{21}$ Mr Bryan Hughes, Managing Director of Pitcher Partners considered that the existing requirements regarding the preparation of remuneration reports were extensive enough, with remuneration reports (following the then IPAA Code of Professional Practice) averaging 20 pages in length. Mr. Hughes further questioned whether all stakeholders read such a lengthy report, as well as, whether the information is meaningful and able to be understood, if read.

Such concerns emphasise the need to determine the underlying reasons for complaints regarding CIP remuneration. Namely, do complaints arise from deliberate or inadvertent failure of CIPs to obtain reasonable compensation for the standard of insolvency work completed or from a failure on the part of stakeholders (principally unsecured creditors) to understand the role of the CIP in the resolution of a company's insolvency and/or what amounts to reasonable remuneration for undertaking this role? ASIC statistics on the nature of CIP misconduct provide some support for the proposition that the majority of complaints against CIPs (which would include complaints regarding remuneration) arise from a lack of understanding on the part of creditors of the CIP's role in the insolvency process.

Table 1 provides a summary of the outcomes resulting from alleged misconduct reports against registered liquidators during the years: 2011-2013.

\footnotetext{
${ }^{20}$ Commonwealth of Australia Treasury, Financial System Inquiry, Final Report, March 1997, 191.Available at http://fsi.gov.au/files/2014/12/FSI_Final_Report_Consolidated20141210.pdf

${ }^{21}$ The Senate Economics References Committee, Parliament of Australia, The regulation, registration and remuneration of insolvency practitioners in Australia: the case for a new framework (2010) [8.59]. Available at http://www.aph.gov.au/Parliamentary_Business/Committees/Senate/Economics
} 


\section{Insert Table 1: Outcomes Resulting from Alleged Misconduct Reports \& Inquiries ${ }^{22}$}

Consistently over the three year period: 2011-2013 the majority of complaints concerning insolvency practitioners have been resolved by "educating the complainant of the applicable law/ practice or the provision of information pertaining to the normal practice of the insolvency process."23

During 2011, ASIC commenced its remuneration monitoring project. The project focuses primarily on disclosure, but also considers the reasonableness of the external administrator's remuneration. Table 2 summarises what were the most popular outcomes arising from a detailed review of liquidator's remuneration reports.

\section{Insert Table 2: Most Popular Outcomes Arising from Remuneration Monitoring Project $^{24}$}

Table 2 data appears to confirm two propositions: that in the majority of cases, registered liquidators are preparing remuneration reports and seeking approval of their remuneration in accordance with the standards imposed by the Corporations Act and ARITA's code of conduct; and that stakeholder complaints relate to a lack of knowledge or understanding of the CIPs obligations or what amounts to reasonable remuneration for the CIP fulfilling these

\footnotetext{
${ }^{22}$ Australian Securities and Investments Commission, Report 389 ASIC Regulation of Registered Liquidators: January to December 2013 available at http://asic.gov.au/regulatory-resources/find-a-document/reports/rep-389asic-regulation-of-registered-liquidators-january-to-december-2013/ ; Australian Securities and Investments Commission, Report 342 ASIC Regulation of Registered Liquidators: January to December 2012 available at http://asic.gov.au/regulatory-resources/find-a-document/reports/rep-342-asic-regulation-of-registeredliquidators-january-to-december-2012/; Australian Securities and Investments Commission, Report 287 ASIC Regulation of Registered Liquidators: January to December 2011, available at http://asic.gov.au/regulatoryresources/find-a-document/reports/rep-287-asic-regulation-of-registered-liquidators-january-to-december-2011/ ${ }^{23}$ Australian Securities and Investments Commission, Report 287 ASIC Regulation of Registered Liquidators: January to December 2011, 25 available at http://asic.gov.au/regulatory-resources/find-a-document/reports/rep287-asic-regulation-of-registered-liquidators-january-to-december-2011/

${ }^{24}$ Ibid.
} 
obligations. Anderson and Brown have previously identified this lack of knowledge, as part of their Insolvency Regulation Evaluation model, referring to the 'feasibility gap’

as a measure of unreasonable expectations on behalf of relevant stakeholders, such as creditors... when an entity becomes insolvent and what an insolvency practitioner can reasonably be expected to achieve in relation to insolvency outcomes. Reducing the feasibility gap requires the scope of the insolvency profession's role in the event of insolvency and ... as a "gatekeeper" of financial markets be clearly defined so that misconceptions ... held by creditors ...can be identified and resolved. ... if unrealistic or unreasonable expectations of creditors (exist), then the resolution is more likely to lie in education of the general community, rather than further regulation. ...if the feasibility gap is not clearly identified and articulated, any measure that simply increases the volume of information contained in the remuneration reports without consideration of causes of the feasibility gap will fall short of achieving the desired outcome $e^{25}$.

Support for the existing level of regulatory disclosure required in Australia is provided by Elaine Kempson, “...there is much that we can learn from Australia and from the ... IPAA (now ARITA) Code of Professional Practice in particular." "26 Thus, it is the author's contention that the information asymmetries that exist between creditors and insolvency practitioners regarding reasonable remuneration for CIPs cannot be addressed by regulation requiring further disclosure. Rather, creditors must be educated to understand the role and obligations of CIPs and the reasonable costs ${ }^{27}$ to be incurred in meeting these obligations. Armed with such knowledge creditors are more likely to identify poorly performing CIPs or those CIPS guilty of misconduct. Creditor education has been previously identified as a

\footnotetext{
${ }^{25}$ Colin Anderson and Catherine Brown, "Mind the insolvency gap: Lessons to be learned from audit expectations gap theory" (2014) 22 Insolv LJ 178,189.

${ }^{26}$ Elaine Kempson, Report to the Insolvency Service, (July 2013) Available at http://www.bis.gov.uk/insolvency/insolvency-profession/review-of-IP-fees

${ }^{27}$ This educative role may include the collection, and publication of comparative CIP remuneration fee data based on company size and asset disposals to assist unsecured creditors to determine the reasonableness of remuneration charged.
} 
neglected area, arising from a lack of communication between ASIC (as regulator) and creditors. ${ }^{28}$ The appointment of an Insolvency Ombudsman has been previously suggested as a means of providing such an educative role to creditors. ${ }^{29}$

However, educating creditors to assess the reasonableness of CIP remuneration where timebased charges are used may prove problematic. ${ }^{30}$ In Re AAA Financial Intelligence Ltd (in liquidation) (No 2) [2014] NSWSC 1270 (In Re AAA No2) Brereton J considered whether the formula of time reasonably spent at standard hourly rates provides the proper measure of reasonable remuneration. The circumstances of In Re AAA No2 were that the amount of liquidator's remuneration and disbursements (representing $70 \%$ of the adviser funds) would practically exhaust the trust funds available such that the primary beneficiaries of the liquidation were the Liquidators. Relying upon Ferris J in Mirror Group Newspapers plc v Maxwell (No2) [1988] 1 BCLC 638 at 648 Brereton J emphasised that liquidators are under a

fiduciary duty to protect, get in and realise assets and property belonging to creditors or beneficiaries and pass it on to them and in so doing are expected to exercise proper commercial judgement in carrying out their duties and to account both for the way in which they exercised their powers and for the property dealt with. Where the sole or dominant beneficiary of a liquidation is not the creditors, but the liquidator, that fundamental purpose has not been achieved.

While recognising that the proper pursuit of debtors and or officers for the benefit of creditors may result in a return of funds that does not exceed the liquidator's reasonable remuneration and disbursements, Brereton J considered that remuneration claims where the liquidator

\footnotetext{
${ }^{28}$ The Senate Economics References Committee, Parliament of Australia, The regulation, registration and remuneration of insolvency practitioners in Australia: the case for a new framework (2010) [6.27].

${ }^{29}$ Ibid, [8.75],[10.37].

${ }^{30}$ Criticisms of time based charging have included, 'reduces the ability of clients to assess the reasonableness of the remuneration and to compare services between practitioners, as there is little indication of the total cost'. See, Australian Government, Treasury, A Modernisation and Harmonisation of the Regulatory Framework Applying to Insolvency Practitioners in Australia, Options Paper (2 June 2011) available at http://www.treasury.gov.au/ConsultationsandReviews/Consultations/2011/A-Modernisation-andHarmonisation-of-the-Regulatory-Framework.
} 
appears to be the main beneficiary of the liquidation should be closely scrutinised. ${ }^{31}$ In scrutinising the liquidator's remuneration (which was based on time-based costing) in $R e$ AAA No 2 Brereton J considered, time-based costing was an unreliable measurement of liquidator remuneration, bearing little relationship to the value achieved for the client, particularly in smaller liquidations. The method's shortcomings included: costs inflated by unproductive hours ${ }^{32}$ or deliberate exploitation; ${ }^{33}$ incapacity to be accurately audited; and an inability to reflect some of the statutory guidance factors for determining reasonable remuneration. $^{34}$

In lieu of time costing, Brereton J. preferred to adopt an 'ad valorem’ or 'value’ focussed approach in fixing the Liquidator's remuneration on the basis that ad valorem remuneration took into consideration proportionality (the difficulty or importance of the task within the context of the work performed), the risk assumed, the value generated and was specifically provided for as a means of calculating the remuneration of court appointed liquidators. ${ }^{35}$ It is noteworthy that the EBRD proposed in its Discussion Report on remuneration that, "it is likely that an IP will perform the work involved competently and efficiently if provision is also made for creditors and an IP to agree the basis of remuneration in rescue and more complex cases where the tariff would otherwise discourage highly skilled IPs to become engaged.”36

\footnotetext{
${ }^{31}$ In Re AAA No 2 [2014] NSWSC 1270 [37]]

${ }^{32}$ In Re AAA No 2 [2014] NSWSC 1270 [37] Brereton J referred to PO Lawrence, J in Re Carton Ltd (1923) 39 TLR 194 at 197.

${ }^{33}$ In Re AAA No 2 [2014] NSWSC 1270 [40] \& [42] Brereton J endorsed comments made by Finkelstein J in Re Stockford Ltd; Korda [2004] FCA1682 [46] and McLure JA in Conlan v Adams [2008] WASCA 61 [47].

${ }^{34}$ In Re AAA No 2 [2014] NSWSC 1270, [44].Of the factors referred to in s504 (2) Corporations Act 2001, in particular: quality of the work performed s 504(2)(d); the degree of risk and responsibility involved s504(2)(g); and the value and nature of the property involved s504(2)(h).

${ }^{35}$ In Re AAA No 2 [2014] NSWSC 1270 [59].

${ }^{36}$ EBRD above $n 13$.
} 
Value pricing is used in other industries such as information technology, engineering, law and finance. ${ }^{37}$ The perceived advantages of value pricing are that the work is costed upfront, based upon the client's perception of its worth, creating certainty and transparency. ${ }^{38}$ However, currently value-based pricing is more popular in the United States and the United Kingdom than in Australia. ${ }^{39}$

Notably, the UK Insolvency Service, ${ }^{40}$ in answer to criticisms of the use of time-costing by the Office of Fair Trading ${ }^{41}$ and Professor Elaine Kempson ${ }^{42 i}$ proposed to restrict an insolvency practitioner's use of time costing as a basis for remuneration, except in cases where tight control was exercised over the insolvency work done, either by a creditors’ committee or secured creditor. The Kempson review considered that restricting the use of time-cost basis would simplify the process of oversight by unsecured creditors. However, the question then remains, and is considered below, whether creditors having identified poorly performing CIPs or those CIPS guilty of misconduct have the necessary powers or inclination to remove them.

\subsection{Inadequate Competition}

A profile of Australia’s corporate insolvency industry shows as at 31 December, 2013 a small industry of 689 registered liquidators ${ }^{43}$ (of which 583 were also official liquidators ${ }^{44}$ ) with

\footnotetext{
${ }^{37}$ Susan Muldowney, “Cash on the Dial”(November, 2014) In the Black, 66.

${ }^{38}$ Ibid, 66, 68.

${ }^{39}$ Ibid, 66.

${ }^{40}$ United Kingdom, The Insolvency Service, Consultation Report, (February 2014) Strengthening the regulatory regime and fee structure for insolvency practitioners, available at https://www.gov.uk/government/uploads/system/uploads/attachment_data/file/280880/Strengthening_the_regul atory_regime_and_fee_structure_for_insolvency_practitioners.pdf

${ }^{41}$ United Kingdom, Office of Fair Trading, The Market for Corporate Insolvency Practitioners , A Market Study June, 2010, available at http://webarchive.nationalarchives.gov.uk/20140402142426/http:/www.oft.gov.uk/shared_oft/reports/Insolvenc y/oft1245

${ }^{42}$ Elaine Kempson, Review of Insolvency Practitioner Fees Report to the Insolvency Service (July 2013). Available at http://www.bis.gov.uk/insolvency/insolvency-profession/review-of-IP-fees

${ }^{43}$ Although comparably larger than the United Kingdom where, as at 1 January 2014 there were 1,677 insolvency practitioners in the United Kingdom.
} 
$49 \%$ operating in a firm of 10 or more liquidators and a further $42 \%$ operating in a firm of four or less liquidators. ${ }^{45}$ The majority of external administration appointments concern small to medium proprietary limited companies, where unsecured creditors are unlikely to recover more than 10c in the $\$$ of their debt. ${ }^{46}$ Table 3 indicates that during the three years 1 July 2011 to 30 June 2014, these companies predominantly had less than $\$ 100,000$ in assets and less than \$1m in liabilities. More than a majority of external administrations have no secured creditors and unsecured creditors number less than fifty.

\section{Insert Table 3 Profile of Companies in External Administration ${ }^{47}$}

The above profile of an average external administration provides the context for and illustrates the difficulty of fee assessment, negotiation and settlement for a CIP in an insolvency administration. Australia’s corporate insolvency market can be subdivided into two markets, colloquially called the secured and unsecured market. Within the secured market, CIPs have identifiable clients, typically large scale institutional lenders such as banks, who provide repeat work, but whose selection process is highly price competitive. In the unsecured market , the CIP has no identifiable client who provides repeat work. Rather the CIP works for a diverse range of unsecured creditors being individuals or organisations, whose diverse interests may adversely affect their ability to organise, co-operate and be engaged in the effective review of remuneration claims or the monitoring of the administration’s progress. ${ }^{48}$

\footnotetext{
${ }^{44}$ Official liquidators conduct court appointed windings-up and are drawn from the ranks of registered liquidators.

${ }^{45}$ Australian Securities and Investments Commission, Report 389 ASIC Regulation of Registered Liquidators: January to December 2013, Appendix 1, 32 available at http://asic.gov.au/regulatory-resources/find-adocument/reports/rep-389-asic-regulation-of-registered-liquidators-january-to-december-2013/

${ }^{46}$ A market study of CIPs in the United Kingdom found that within a sample of 500 administrations, unsecured creditors experienced a recovery rate on average of 4 per cent.

47 Source: ASIC Report 412 Insolvency Statistics: External Administrators’ Reports (July 2013 to June 2014) available at http://asic.gov.au/regulatory-resources/find-a-document/statistics/insolvency-statistics/

${ }^{48}$ See, Australian Government, Treasury, A Modernisation and Harmonisation of the Regulatory Framework Applying to Insolvency Practitioners in Australia, Options Paper (2 June 2011), 4 available at
} 
Given the similarity between the United Kingdom’s and Australia’s corporate insolvency industry profile, ${ }^{49}$ an opportunity exists to be informed by two recent independent reports by the Office of Fair Trading (2010) ${ }^{50}$ and Professor Elaine Kempson (2013) ${ }^{51}$ specifically addressing IP remuneration in the UK. Both reports have highlighted problems in the UK CIP market which may also be reflective of Australia’s CIP market: that there is “clear evidence of the difficulty unsecured creditors face in controlling CIP fees”. ${ }^{52}$ In the United Kingdom this failure centres on the inability of unsecured creditors to effectively oversee the work undertaken by IPs, resulting in higher costs. ${ }^{53}$ Qualitative research with unsecured creditors indicates a lack of unsecured creditor engagement with the appointment of a CIP and the determination of CIP remuneration. ${ }^{54}$ Interviews conducted with unsecured creditors revealed that they do not attend creditors meetings due to a belief of their inability to influence decision-making at such meetings, especially with respect to the fees charged by CIPs. ${ }^{55}$ It has been suggested that this lack of oversight by unsecured creditors further contributes to inadequate competition for CIP appointments. ${ }^{56}$ A similar market failure to control CIP fees would appear to exist within Australia. In Re AAA Financial Intelligence Ltd (in liquidation)

\footnotetext{
http://www.treasury.gov.au/ConsultationsandReviews/Consultations/2011/A-Modernisation-andHarmonisation-of-the-Regulatory-Framework.

${ }^{49}$ Professor Kempson identified in her report, 'In a great many respects the situation in Australia (referring to insolvency practitioner market failure) has much in common with that in the UK. Insolvency legislation is very similar, cases are normally charged on a time-cost basis and attendance by unsecured creditors meetings is low.' Elaine Kempson, Review of Insolvency Practitioner Fees Report to the Insolvency Service July 2013, 42.

${ }^{50}$ The Office of Fair Trading, “The market for corporate insolvency practitioners: A market study” 2010 available at http://webarchive.nationalarchives.gov.uk/

${ }^{51}$ Elaine Kempson, "Review of Insolvency Practitioner Fees, Report to Insolvency Service” 2013 available at https://www.gov.uk/government/publications/insolvency-practitioner-fees-a-review

${ }^{52}$ United Kingdom Insolvency Service, 'Strengthening the regulatory regime and fee structure for insolvency practitioners’ Consultation Paper February 2014, 2, 40. In corporate insolvencies the creditors are in many cases trades-people and therefore much less likely to have experience of more than one insolvency, whereas, in personal bankruptcy, the creditors are more likely to be financial services firms and local authorities who have such experience.

53 The Office of Fair Trading reported in 2010 that in just over a third of insolvency cases where unsecured creditors receive a dividend, fees were estimated to be $9 \%$ higher in like-for-like cases than where secured creditors control an IP fees. The Office of Fair Trading, "The market for corporate insolvency practitioners: A market study” 2010 available at http://webarchive.nationalarchives.gov.uk/ para 1.18.

${ }^{54}$ Elaine Kempson, “Review of Insolvency Practitioner Fees, Report to Insolvency Service” 2013, 18 available at https://www.gov.uk/government/publications/insolvency-practitioner-fees-a-review .

55 Ibid, 19-20. Where a time-cost basis was used to determine IP fees, unsecured creditors found they lacked the information to determine whether the hourly rates were reasonable or the time charged justifiable.

${ }^{56}$ Ibid 21.
} 
(No 2) [2014] NSWSC 1270 Brereton J confirmed the lack of competition within the CIP market meant market forces were unable to control liquidators' (hourly) charges as creditors are generally price takers rather than price makers in terms of negotiating a liquidator's remuneration. ${ }^{57}$

The Insolvency Service in the United Kingdom has proposed increasing creditor engagement and thereby indirectly increasing competition within the UK CIP market by providing educational materials to creditors “on how to appoint an IP and get involved in negotiating fees, including the best way to obtain competitive quotes”58 (internet based). A further suggestion was to determine the feasibility of "publicising comparative fee data by asset size, and possibly by sector, to allow creditors to make a more informed choice” by providing them with a basis on which to question the CIP's proposed fee. The costliness of such a labour intensive process was also recognised. ${ }^{59}$ The EBRD Discussion Paper confirmed the need for the law to provide for IPs to disclose up to date information on fees to enable creditors and other interested parties to assess the basis on which the IPs fees have been calculated. ${ }^{60}$

An alternative suggestion for unsecured creditors' lack of engagement and attendance at meetings is their position in the statutory priority order for repayment of debt. Unsecured creditors believe a consequence of their low priority is they will receive very little or no return on their unpaid debt. ${ }^{61}$ Preferential creditors, more powerful, knowledgeable and more easily mobilised than unsecured creditors, may attend creditors’ meetings. However,

\footnotetext{
${ }^{57}$ Brereton $\mathrm{J}$ did recognise that independence, rather than comparative cost of the CIP, is the dominant consideration in selecting a liquidator.

${ }^{58}$ United Kingdom Insolvency Service, 'Strengthening the regulatory regime and fee structure for insolvency practitioners’ Consultation Paper February 2014, 26.

${ }^{59}$ Ibid.

${ }^{60}$ EBRD, above n13,18.

${ }^{61}$ Association of Business Recovery Professionals, OFT market study into corporate insolvency: R3's response, 5. Available at https://www.r3.org.uk/media/documents/policy/policy_papers/corporate_insolvency/R3_responds_to_OFT_rec ommendations.pdf
} 
creditors are not a homogeneous group, and while unsecured creditors and preferential creditors may share collective concerns regarding the CIP's remuneration levels, those collective concerns may dissipate if priority creditors are assured of recovering their debt, so that they do not seek to exercise their rights to review costs. Assessing the various reasons and determining the primary reason for creditor disengagement (if one exists) within Australia's corporate insolvency market is essential in forming effective measures to reduce creditor disengagement as discussed below.

\section{PROPOSED 2014 REFORMS TO THE REMUNERATION OF CIPs.}

\subsection{Addressing Information Asymmetries}

The current rules in relation to approval and disclosure of CIP remuneration remain substantially unaffected by the ILRB 2014 reforms. ${ }^{62}$ The focus of the 2014 reforms is to consolidate, substantially align and simplify the current rights of IPs, in any given administration, to claim remuneration. ${ }^{63}$ Nevertheless, the current rules regarding the power of the chair to exercise a casting vote will be amended where a resolution is split between the majority by number and value with respect to approval of a CIP's remuneration (or the removal of a CIP from an administration). ${ }^{64}$ In such circumstances, the amendment will provide that the Chair will not have a casting vote and the motion for approval of the resolution will be defeated. In respect of non-remuneration or non-removal matter, the Chair will retain a casting vote.

\footnotetext{
${ }^{62}$ All current obligations on IPs to provide information to creditors as part of the remuneration approval process are appealed by the ILRB 2014. However, the Insolvency Practice Rules will replicate the current obligations to provide remuneration reports as part of the approval process provided for in s449E, s473, s495 and s499 Corporations Act 2001 (Cth).

${ }^{63}$ See Schedule 2 Part 1 ss60-5 ILRB 2014 where an external administrator is entitled to receive remuneration in accordance with the remuneration determination (s60-10) made by creditors, committee of inspection or by the Court.

${ }^{64}$ Commonwealth of Australia, Insolvency Practice Rules Proposal Paper, November, 2014, 22 [3.5.3].
} 
Where remuneration is specified to be determined on a time - cost basis, a cap is to be imposed on the amount of remuneration to be received. ${ }^{65}$ If no remuneration determination is made the administrator is entitled to receive reasonable remuneration, ${ }^{66}$ however such remuneration must not exceed the maximum default amount. ${ }^{67}$ The breadth of eligible persons able to apply to the Court for review of the remuneration determination has been expanded to include: ASIC; the external administrator; a person with a financial interest in the external administration (creditor or member) or an officer of the company. ${ }^{68}$ However the factors the Court considers in undertaking such a review have not been altered. Having reviewed the CIP remuneration the Court may order its repayment.

To address information asymmetries between creditors and CIPs, proposed reforms allow creditors by resolution ${ }^{69}$ or individually ${ }^{70}$ to make reasonable requests for information, reports or documents from CIPs who are obliged to meet such requests. By CIPs meeting such requests, it is considered that creditors then have the ability to inform themselves of the matters concerning the insolvency and exercise their rights where appropriate. An unreasonable request is defined in the proposed Insolvency Practice Rules (IPR) ${ }^{71}$ to include when there are not sufficient resources available to comply with the request, or the request is deemed vexatious. Certain requests are deemed to be reasonable requests at all times (unless the request is vexatious) such as: current creditor lists, detailed work in progress reports including description of work completed, work underway and work still to be undertaken. ${ }^{72}$

\footnotetext{
${ }^{65}$ Schedule 2 Part 1 Section 60-10(4) ILRB 2014.

${ }^{66}$ Schedule 2 Part 1 Section s60-5(2) ILRB 2014.

${ }^{67}$ Schedule 2 Part 1 Section s60-15 ILRB 2014. The maximum default amount is $\$ 5000$ as from 1 July 2015 but will be indexed on and thereafter 1 July 2016.

68 Schedule 2 Part 1Section 60-11 ILRB 2014.

${ }^{69}$ Schedule 2 Part 1 Section 70-40(1) ILRB 2014.

${ }^{70}$ Schedule 2 Part 1 Section 70-45 ILRB 2014.

${ }^{71}$ Schedule 2 Part 1 Section 70-50 ILRB 2014 and Commonwealth of Australia, Insolvency Practice Rules, Proposal Paper, November, 2014, 22[3.71].

${ }^{72}$ Commonwealth of Australia, Insolvency Practice Rules, Proposal Paper, November, 2014, 22[3.7.2].
} 
The CIP must comply with these reasonable requests no later than five business days after the request has been communicated to the CIP. ${ }^{73}$

To a large extent the proposed reforms provide information to 'insolvency literate creditors ${ }^{74}$ who would appear to know what further information, report or document is required. To that end, these reforms do not address what has been earlier identified and referred to as the 'feasibility gap,' nor do these reforms address the means of overcoming this gap by 'creditor education'. To raise creditors' appreciation of what is a reasonable remuneration fee, a publicly accessible database which provides for the collection and publication of statistical data regarding CIP remuneration charged, the value of asset recoveries and returns to creditors has been previously suggested, ${ }^{75}$ yet remains to be implemented. An industry ombudsman has also been recommended as a means of educating creditors and the public regarding what is a reasonable fee structure for CIPs. ${ }^{76}$

\subsection{Increasing CIP Competition}

A number of proposed reforms seek to increase the level of CIP competition. However, there are additional costs associated with the proposed reforms. Firstly, it is proposed that there will be only one class of CIP: a registered liquidator, capable of performing all the functions previously restricted to official liquidators and the class of Official liquidators will be abolished. ${ }^{77}$ Qualifications to apply for registration as a liquidator have been expanded to remove the current preference for accounting studies over legal studies. ${ }^{78}$ Although a prescribed level of formal tertiary studies in insolvency must be completed, there is reduction

\footnotetext{
${ }^{73}$ Commonwealth of Australia, Insolvency Practice Rules, Proposal Paper, November, 2014, 23 [3.7.2].

${ }^{74}$ Meaning creditors who have an understanding of the CIP's role and what amounts to reasonable remuneration for the CIP fulfilling this role.

75 The Senate Economics References Committee, Parliament of Australia, The regulation, registration and remuneration of insolvency practitioners in Australia: the case for a new framework (2010) [8.69] - [8.73].

${ }^{76}$ Ibid, [8.75]-[8.76].

${ }^{77}$ Schedule 2 Part 1 Section 20-5 ILRB 2014.

${ }^{78}$ Schedule 2 Part 1 section 20-20(4)(a) ILRB 2014, Commonwealth of Australia, Insolvency Practice Rules Proposal Paper,3.1. Division 15 November, 2014 Part 3.1 Rule 101.
} 
in the length of required senior full time experience to not less than three years in the preceding five years. ${ }^{79}$ The proposed reforms allow an applicant to specialise by applying for limited registration. ${ }^{80}$ For example, where a CIP may only act as a registered liquidator where the person is appointed as a receiver or as a receiver/ manager. The proposed widening of education requirements, the lessening of necessary work experience in conjunction with the removal of the Official liquidator class and the ability to control the number of specialised CIPs may increase the number of participants within the CIP market leading to a lowering of remuneration costs. Alternatively, the broadening of qualification standards and the reduction in required insolvency experience may reduce the academic and professional quality of entrants to the insolvency profession, increasing remuneration costs with insolvencies taking longer to complete. There are also additional establishment and oversight costs associated with ASIC convening a registration committee ${ }^{81}$ to consider CIP applications for registration as a liquidator.

To prevent the claiming of excessive remuneration by CIPs, the ILRB 2014 provides creditors with two additional powers to control CIP remuneration. Firstly, one or more creditors $^{82}$ or creditors by resolution ${ }^{83}$ may appoint a registered liquidator to review the remuneration of the external administrator of the company or costs or expenses incurred by external administrator. In each case, the remuneration and/ or costs or expenses which are to be reviewed and the manner in which the cost of the review is to be determined must be specified. ${ }^{84}$ Subject to a Court order, ${ }^{85}$ where the review is a result of one or more creditors appointing a registered liquidator, the cost of the review is directly borne by the appointing

\footnotetext{
${ }^{79}$ Ibid.

${ }^{80}$ Schedule 2 Part 1 Section 20-20(6) ILRB 2014.

${ }^{81}$ Schedule 2 Part 1 Section 20-10 ILRB 2014.

${ }^{82}$ Schedule 2 Part 1 Section 90-24 (4) ILRB 2014. However, an appointment may only be made if the external administrator of the company agrees: Schedule 2 Part 1 s90-24(5) ILRB 2014.

${ }^{83}$ Schedule 2 Part 1 Section 90-24(2) ILRB 2014.

${ }^{84}$ Schedule 2 Part 1 Section 90-24(3) (appointment by resolution) or s90-24(6) (appointment by one or more creditors) ILRB 2014.

${ }^{85}$ Schedule 2 Part 1 Section 90-27(2) ILRB 2014.
} 
creditors. ${ }^{86}$ Otherwise, where the review is a result of a creditors' resolution the cost is an external administration expense ${ }^{87}$ and to that extent is an indirect cost to the creditors. In either case, there is a reduced amount of monies available to creditors. Thus, creditors may consider the cost of such reviews as prohibitive which will deter their use. The Senate Committee in 2010 suggested an 'Insolvency Ombudsman' ${ }^{88}$ to perform a similar service as an objective observer at no cost to the creditor.

Secondly, creditors may by resolution at a meeting, remove the external administrator, if the requisite notice of the meeting has been given. ${ }^{89}$ Where creditors are unhappy with the performance of the insolvency practitioner it will be possible for a majority of creditors in number and value to pass a resolution ${ }^{90}$ at a creditors' meeting to remove the insolvency practitioner and appoint another. No particular grounds for removal are required, however, the former external administrator, may apply to the court to be reappointed. The Court may make such an order if satisfied that the removal was an improper use of the creditors' powers. This power will provide creditors with the means to remove CIPs who may guilty of misconduct, or poor performance, including excessive overcharging of remuneration, without incurring the prohibitive cost of applying for and attending a court hearing. At face value, providing creditors with such a power to remove a CIP may reduce creditor disengagement with the insolvency process as creditors perceive they have a voice in insolvency procedures and thereby increase the level of competition within the CIP market. By granting creditors the rights: to make reasonable requests for information from CIPS; to appoint a registered liquidator to review the external administrator's remuneration and to

\footnotetext{
${ }^{86}$ Schedule 2 Part 1 Section 90-27(1)(a) ILRB 2014.

${ }^{87}$ Schedule 2 Part 1 Section 90-27(1)(b) ILRB 2014.

${ }^{88}$ The Senate Economics References Committee, Parliament of Australia, The regulation, registration and remuneration of insolvency practitioners in Australia: the case for a new framework (2010) [10.35] -[10.41].

${ }^{89}$ Schedule 2 Part 1Section 90-35 ILRB 2014. Notice, must be at least 5 business days.

${ }^{90}$ Schedule 2 Part 1 s90-35(1) ILRB 2014
} 
remove a CIP from office, it is considered that creditors will be better informed, able to recognise CIP misconduct sooner and have the opportunity to effectively protect their own interests. Strengthening creditor engagement with the insolvency process will place downward pressure on the price and upward pressure on the quality of insolvency services provided by CIPs, resulting in a more competitive market. For these measures to be effective, however, the primary reason for unsecured creditor disengagement in Australia must be unsecured creditors’ perception of inability to influence decision-making. In such circumstances, the empowerment measures will provide a voice to unsecured creditors in decision-making. Conversely, if unsecured creditors are disengaged because they perceive that they will receive no or a very low level of dividend as a product of their low statutory order of debt repayment ranking, then these empowerment measures will have little, if any effect, in engaging unsecured creditors in the insolvency process, or increasing price competitiveness in the CIP market. Preferential creditors are considered to be engaged and capable of exercising downward pressure on the level of remuneration fees. However, it is suggested that their level of engagement is restricted to the recoverability of their debt, and does not extend to the recoverability, if any, of unsecured creditors debts.

\section{CONCLUSION}

Unlike insolvency law reforms proposed in the United Kingdom, the ILRB 2014 does not recommend restricting the use of the time cost basis as a method of calculating CIP remuneration. Rather, Australia insolvency law continues to rely largely upon the market to determine the most cost - effective remuneration - setting mechanism for CIPs.

However, the ILRB 2014 remuneration reforms seek to improve the price competitiveness of the CIP market by two means. Firstly, increasing the number of CIP market participants by broadening the qualifications to apply for registration as a liquidator which may directly 
impact on CIP quality and thereby indirectly increase CIP remuneration levels as insolvency completion rates are extended. Secondly, by granting creditors, as principal stakeholders in the corporate insolvency market, further powers of external administrator review and/or removal so as to influence the price of insolvency services. Nevertheless, the granting of these additional powers to creditors will be ineffective, if creditors are not motivated to exercise these powers. Given the divergent reasons, outlined in the paper, for unsecured creditors non - attendance at creditor's meetings and it is argued preferential creditors' failure to engage with unsecured creditors' interests, doubt surrounds the effectiveness of the proposed creditor empowerment measures to increase creditor engagement with the appointment (including remuneration approval) and removal of CIPs and thereby increase price competitiveness in the CIP market.

A further key aim of the ILRB 2014 is to improve the overall confidence in the professionalism and competence of insolvency practitioners. Despite this aim, the proposed reforms to address information asymmetries between creditors and CIPs provide information access only to those creditors who may already be considered insolvency literate. The reforms do not address the 'feasibility gap', referred to in the paper, which may account for part, if not all, of the public's perceived lack of confidence in CIPs, nor do these reforms address the means of overcoming this gap by providing 'creditor education'.

Given the doubts expressed in the paper of the effectiveness of the latest remuneration reforms to promote CIP market competition or improve the public's confidence in the insolvency profession, it is considered that the protracted process of CIP remuneration reform in Australia will continue. 


\section{Appendix I}

\section{Tables \& Illustrations}

\section{Table 1: Outcomes Resulting from Alleged Misconduct Reports \& Inquiries}

\begin{tabular}{|l|c|c|c|}
\hline \multicolumn{1}{|c|}{ Outcome } & $\begin{array}{l}\text { 2011 Calendar Year } \\
539 \text { reports/inquiries }\end{array}$ & $\begin{array}{c}\text { 2012 Calendar Year } \\
477 \text { reports/inquiries }\end{array}$ & $\begin{array}{c}\text { 2013 Calendar Year } \\
\text { 446 reports/inquiries }\end{array}$ \\
\hline $\begin{array}{l}\text { Conduct: a serious deliberate } \\
\text { or conscious act or omission } \\
\text { committed }\end{array}$ & $16 \%$ & $9 \%$ & $14 \%$ \\
\hline $\begin{array}{l}\text { Procedural : less significant and } \\
\text { inadvertent misconduct } \\
\text { identified }\end{array}$ & $33 \%$ & $22 \%$ & $25 \%$ \\
\hline $\begin{array}{l}\text { Educative: complainant } \\
\text { (creditor) educated about the } \\
\text { applicable law or normal } \\
\text { insolvency practice. }\end{array}$ & $51 \%$ & $69 \%$ & $61 \%$ \\
\hline
\end{tabular}

Table 2: Most Popular Outcomes Arising from Remuneration Monitoring Project

\begin{tabular}{|l|c|c|c|}
\hline \multicolumn{1}{|c|}{ Outcome } & $\begin{array}{c}\text { 2011calendar year } \\
\text { Remuneration } \\
\text { Reports } \\
\text { Initial Review:199 } \\
\text { Detailed Review: 24 }\end{array}$ & $\begin{array}{c}\text { 2012 calendar year } \\
\text { Remuneration Reports } \\
\text { Initial Review: 335 } \\
\text { Detailed Review: 40 }\end{array}$ & $\begin{array}{l}\text { 2013 calendar year } \\
\text { Remuneration Reports } \\
\text { Initial Review: 296 } \\
\text { Detailed Review: 20 }\end{array}$ \\
\hline Educative outcomes & $29 \%$ & $22.5 \%$ & $53 \%$ \\
\hline $\begin{array}{l}\text { Additional Disclosure } \\
\text { to creditors }\end{array}$ & $45.83 \%$ & $52.5 \%$ & $18 \%$ \\
\hline No Issues & & & \\
\hline
\end{tabular}

Table 3 Profile of Companies in External Administration

\begin{tabular}{|c|c|c|c|}
\hline Characteristic & $\mathbf{2 0 1 1 - 2 0 1 2}$ & $\mathbf{2 0 1 2 - 2 0 1 3}$ & $\mathbf{2 0 1 3 - 2 0 1 4}$ \\
\hline Assets less than \$100,000 & $85 \%$ & $85 \%$ & $86 \%$ \\
\hline $\begin{array}{c}\text { Liabilities equal to or less } \\
\text { than \$250,000 }\end{array}$ & $42 \%$ & $63 \%$ & $65 \%$ \\
\hline $\begin{array}{c}\text { Asset deficiency equal to } \\
\text { or less than \$500,000 }\end{array}$ & $64 \%$ & $68.5 \%$ & $67.3 \%$ \\
\hline No Secured Creditors & $87.5 \%$ & $88.3 \%$ & $89.6 \%$ \\
\hline $\begin{array}{c}\text { Unsecured Creditors less } \\
\text { than 50 }\end{array}$ & $\begin{array}{l}\text { 98\% dividend estimate } \\
\text { less than \$0.11 in \$ }\end{array}$ & $\begin{array}{l}\text { 97\% dividend estimate } \\
\text { less than \$0.11 in \$ }\end{array}$ & $\begin{array}{l}97 \% \text { dividend estimate } \\
\text { less than \$0.11 in \$ }\end{array}$ \\
\hline $\begin{array}{c}\text { Dividends to Unsecured } \\
\text { Creditors }\end{array}$ & & & \\
\hline
\end{tabular}

